\title{
Exposition in Pedagogy
}

\author{
Sashka Jovanovska ${ }^{1}$ \\ ${ }^{1}$ PhD, English professor, North Macedonia
}

\author{
Email: saska dimitrovska@yahoo.com
}

\begin{abstract}
Pedagogy refers to the art and science of teaching, and any methods a teacher uses to teach. Pedagogy is both an art and a science because there are infinite strategies you can learn to help the students, but there is also artistry involved in how you implement those strategies. Since the focus will be on the science side of teaching, and discover the artistry as a beginner working with the students. In this paper consists the discussion of the best ways to impart information upon the students, and how to learn from the experiences and continue improving throughout the career as an educator.
\end{abstract}

Keywords: pedagogy, students, education, discussion.

\section{INTRODUCTION}

Pedagogy is such a complex topic that it could be its own course. Discussing the theories that form a teacher's planning, implementation, and assessment, keep in mind we are giving an overview rather than a comprehensive study. Here are some of the most well-known theories of education.

Considering that education in some form or another has existed since the dawn of man, it is surprising to know there are many different theories on the best way to provide education for students. While many of these theories can work together to inspire teachers in their planning and instruction, some of them directly contradict each other and have led to debates within the profession. Here, is a cover of few of those theories, and how they can inform the teaching.

\section{BLOOM'S TAXONOMY}

Benjamin Bloom studied learning and came to the conclusion that learning activities could be categorized into 6 segments based on the level of thinking that they require. He framed his theory into the shape of a triangle with the lowest-level thinking at the bottom. He did this because even though the lower-level activities require less thinking, they provide the base for higher-level thinking. He believed (as many do) it is hard to extend the learning on a topic if you do not understand the topic itself. We will discuss each category in reverse order, starting with what Bloom labeled as the lowest level of thinking.

Remember: At the base of this triangle, representing the lowest level of thinking, is any activity that requires a student to recall facts and basic concepts. These types of activities are extremely important in a student's learning since it is hard to take the next step without first knowing the basic facts. Activities that require students to remember include defining words, memorizing facts, listing things, and repeating information.

Understand: At the next level of thinking, teachers ask students to comprehend what they are memorizing and repeating. In order for students to explore content in any way, they need to comprehend what they are studying. Activities that require students to explain ideas or concepts include classifying information, describe, discuss, and explain information.

Apply: Once students understand the information they are learning, they can take the next step and apply what they learned to new situations. This displays a higher level of thinking because the student needs to understand the concept enough to apply it to something different. For example: a student may recite Romeo \& Juliet which displays memory. They may comprehend the play enough to explain it, which displays understanding. Now, if they can take that comprehension of the play and use it to understand Othello, they are applying their knowledge. Activities that require students to apply their knowledge include implementing plans, solving problems, and demonstrating knowledge. 
Analyze: True analysis of a concept requires a student to have accomplished all the levels of thinking that come before it. In order to delve into a topic and analyze more than what is explicitly stated, a student needs to understand it completely. When students analyze, they draw connections between ideas and explore connotative and deep meaning. Activities that require students to analyze include differentiating information, organizing information, comparing and contrasting, and experimenting.

Evaluate: The act of evaluating does not necessarily require much thinking; we are constantly in judgment of things we know nothing about. However, to make an accurate judgment about something, you need to completely understand it. Ask the students if Americans were justified in fighting against the British in the American Revolution. They will need to understand how the war began, why each side fought, then make a determination about the colonies' justification. Activities that require students to justify a stand or decision include appraisals, arguments, judgments, and critiques.

Create: The highest level of thinking, according to Bloom, is when you ask the students to synthesize what they have learned and create something new. The idea behind the emphasis on this skill is that students need to understand something completely to now go and create something of their own that is related. Activities that require students to synthesize their knowledge include designing, assembling, constructing, writing (something original), etc.

\section{BEHAVIORISM}

Behaviorist theory is an idea that hinges completely on motivation, and how teachers can get students to succeed in the classroom. While many thinkers contributed to the formation of behaviorism, the ideas can be summed up by the famous experiment conducted by Ivan Pavlov, who proved that a dog could be conditioned to respond to a specific stimulus that does not inherently cause that response. He did this by essentially ringing a bell every time he gave a dog food, to the point where the dog began to salivate in anticipation of food when hearing the bell. After some conditioning with this model, he removed the original stimulus, and found that the dog continued to salivate at the sound of the bell, even when it was not followed by food. The dog had now been conditioned to feel hungry whenever he heard the bell, according to Pavlov.

In order to understand the educational theory, we first need to clear up a few phrases that are misunderstood more often than not. Since behaviorism depends heavily on response to a stimulus, the following phrases refer to the manipulation of stimuli by an outsider (in our case, the teacher):

Positive reinforcement: When an outsider rewards a desired behavior by providing a desired stimulus. An example of this is giving a student a good grade for working hard on an assignment.

Negative reinforcement: This is probably the most misunderstood term in behaviorism. The word negative refers to removal, and the word reinforcement refers to a stimulus. Therefore, negative reinforcement is when an outsider rewards a desired behavior by removing an undesirable stimulus. An example of this would be rewarding a student for good behavior by not yelling at him or her like you normally would.

Positive punishment: This is when an outsider presents the subject with an undesirable stimulus as a consequence of doing something wrong or not doing something right. An example of this would be giving a student an $\mathrm{F}$ for not doing his or her work.

Negative punishment: This is when an outsider removes a desired stimulus from the subject as a consequence of doing something wrong or not doing something right. An example of this would be telling a student he or she can no longer sit with friends because he or she is misbehaving.

Pavlov's experiment displayed classic conditioning, which refers to conditioning involuntary behavior (a dog does not choose to salivate). B.F. Skinner extended this idea, referring to his ideas as operant conditioning, which refers to conditioning voluntary actions through reinforcement and punishment.

\subsection{BEHAVIORISM}

According to this theory:

- Learners are not active in the learning process, but rather passive participants who are simply responding to stimuli.

- Learners begin as a blank page, and behavior is only shaped when stimuli provide either positive or negative reinforcement. 
- The more a behavior is reinforced, whether negatively or positively, the more likely the student is to repeat that behavior.

- In the same way, the more a behavior is punished, whether negatively or positively, the less likely the student is to repeat that behavior.

- In operant conditioning, B.F. Skinner tested the efficacy of different methods of disbursements for reinforcement and punishments. In other words, how often do you need to reinforce or punish behavior in order for it to have the most lasting effect on the subject?

Continuous reinforcement: This is when a subject is reinforced every time he or she performs the desired behavior. Skinner found that this did not motivate subjects. They did not work as hard, and when the reinforcement was removed, they quickly stopped performing the desired behavior.

Fixed ratio reinforcement: This is when the subject is reinforced after a specific amount of time he or she performs the desired behavior. Skinner found that subjects worked harder with this method, and were less likely to stop the desired behavior after the reinforcement was removed. However, this was not the most effective method.

Fixed interval reinforcement: This is when a subject is reinforced after a designated amount of time, provided the desired behavior has been performed at least once during that time. Skinner found the subjects worked moderately hard and were about as likely to stop the behavior as the previous model after the reinforcement was removed.

Variable ratio reinforcement: This is when the subject is reinforced after a random amount of times performing the desired behavior. Skinner found this method made subjects work hard, and took a long time to stop the behavior after the reinforcement was removed.

Variable interval reinforcement: This is when the subject is reinforced after a random amount of time elapsed, providing the subject performed the desired behavior at least once in that time. Skinner found this worked equally as well as the previous model, with subjects working hard and taking a long time to stop the desired behavior after the reinforcement was stopped.

\section{CONSTRUCTIVISM}

Constructivism hinges on the idea that educators need to meet students wherever they are (in terms of skills and knowledge), and help them build on prior knowledge. It is also a theory that seeks to help students find their own way as they experience learning, and come to their own conclusions.

According to this theory:

- The teacher takes a back seat and monitors students as they take control of their learning. A traditional classroom is teacher-centered, but a constructivist classroom is student-centered.

- Students have an active involvement in the lesson. Instead of passively accepting the work given by the teacher and completing it to receive a grade, the student drives the lesson and works toward a goal with the teacher's guidance.

- The class feels less like dictatorship, which is run solely by one person, and more like an environment run by the entire class.

- Teachers allow the students to find their own answers rather than telling the students what answers to look for. Students explore things in their own ways and come to their own conclusions, instead of exploring things the way the teacher tells them to and coming to the conclusions the teacher wants them to come to.

- Teachers encourage students to be autonomous, which means they encourage students to be independent and motivated by their own goals and interests.

Many modern classrooms are moving toward this model, or at least toward a model that is similar, following the next theory we will discuss.

\section{Student-centered learning}

While constructivism is student-centered, there is a movement in modern education for a broader embrace of student-centered learning, even if it is not technically considered constructivist. Since the ideas of student-centered learning have already been covered in constructivism and by the clarity of the title, we will focus this section on how theorists believe student-centered learning benefits the students.

- Research shows that student-centered learning works because a student's potential for learning relies heavily on what he or she already knows. This can affect what new information is 
important to the student, how he or she processes new information, and how he or she determines what is important. With student-centered learning, students are free to work at their own pace, starting at their ability level or base of knowledge.

- One of the most important parts of learning is reflection; having a student look back at what he or she learned, how he or she learned it, and where he or she needs to go from here. A less teacher-centered environment allows students more opportunities for this type of reflection.

- Students who are involved in student-centered learning have reportedly been more motivated and satisfied by the school experience. This is because they are more likely to feel accomplished by their work than if they were simply doing what the teacher told them to do.

- Student-centered learning is open to differentiation, which allows students with developmental, cognitive, or other differences, to all progress. A teacher leading the class is more likely to need all of his or her students to reach a specific spot at the end of the lesson. Students working independently can set their own goals.

- One of the biggest obstacles teachers face is the student who is not engaged. Studies have shown that asking students to move around, control their learning, and take responsibility for their development, lead to more motivation and progress from the students than in traditional classrooms.

\section{CONCLUSION}

Simons and Cleary (2006) found that students participating in community-based experiential learning are more diverse in their attitudes, they are more civically engaged, and they are also more politically aware. Further, Astin, Vogelgesang, Ikeda, and Yee (2000) found that community engaged learning positively impacted academic achievement, leadership skills, career choices, projections of future engagement in service learning and the value youth placed on activism. Given these positive aspects, our aim in is to develop group dynamics, self-reflection, and the ability for students to engage in self-directed learning in order to build the stepping stones that students need to organize and coordinate experiential learning in the community. It is our perception that building self-directed, personally and socially aware students, students who are passionate about learning in and through their communities and interested in making a difference, can be accomplished through various thoughtprovoking, positively-framed assignments and activities.

\section{REFERENCES}

1. Campbell, C., \& Deacon, H. (2006). Unravelling the Contexts of Stigma: From Internalisation to Resistance to Change. Journal of Community and Applied social Psychology. 16, 411-417

2. Cooperrider, D. (1990). Positive image, positive action: The affirmative basis of organizing. In S. Srivastva \& D. L. Cooperrider (Eds.), Appreciative management and leadership: The power of positive thought and action in organizations (pp. 91-125). San Francisco: Jossey-Bass.

3. Connell, J., \& Seville, P. (2007). Process-based learning: A model of collaboration. In A. Hajek \& E. Noseworthy (Eds.), Proceedings of the Association of Atlantic Universities 11th Teaching Showcase; Oct. 28, 2006, Memorial University of Newfoundland (pp. 89-100). Halifax: Association of Atlantic Universities.

4. Etmanski, C., Hall, B. L., \& Dawson, T. (Eds.). (2014). Learning and teaching communitybased research. Toronto: University of Toronto Press.

5. Frank, L.S. (2004). Journey toward the caring classroom. Oklahoma City: Wood 'N' Barnes.

6. Jarvis, P. (2009). Learning to be a person in society. London, UK: Routledge.

7. Knowles, M. S., Holton III, E. F., \& Swanson, R. A. (2012). The adult learner (7th ed.). New York, NY: Routledge.

8. Kolb, D.A. (1984). Experiential learning. Englewood Cliffs, NJ: Prentice Hall. 
9. Kuh, G. D. (2008). High-impact educational practices: What they are, who has access to them, and why they matter. Washington, DC: Association of American Colleges and Universities.

10. Lerner, R., \& Benson, P. (2003). Developmental Assets and Asset-Building Communities. New York: Kluwer Academic/Plenum Publishers.

11. Lewin, K. (1948). Resolving social conflicts: Selected papers on group dynamics. New York: Harper.

12. Maher, P.T., \& Root, E.L. (2015). Learning to learn: Creating community before cramming in content. In J. Loxton (Ed.). Proceedings of the 2014 Association of Atlantic Universities Teaching Showcase; October 18 2014, Cape Breton University, Sydney, NS (pp. 53-59). Halifax: Association of Atlantic Universities.

13. Morgan, R. (2004). Perseverance: The story of Cape Breton's university college 1952-2002. Sydney: UCCB Press.

14. NSSE (National Survey on Student Engagement). (2015). High impact practices. Available at http://nsse.iub.edu/html/high_impact_practices.cfm. Accessed on Jan. 2, 2015.

15. O'Connell, T.S., \& Cuthbertson, B. (2009). Group dynamics in recreation and leisure: Creating conscious groups through an experiential approach. Champaign, IL: Human Kinetics.

16. Preziosi, R. C. \& Gooden, D. J. (2002). Using appreciative learning in executive education. New Horizons in Adult Education, 16(1), 10-16.

17. Rasmussen, D. (2015). Cutural Survival, Voices Issue 1.1. Retrieved from https://www.culturalsurvival.org/publications/voices/derek-rasmussen/cease-do-evil-then-learndo

18. Ryan, J. (2016). The violence of low expectations and poor educational outcomes, presentation for the Learning Circle, United Way. Retrieved from https://issuu.com/actyouth/docs/act_violenceoflowexpectations

19. Schenck, J., \& Cruickshank, J. (2015). Evolving Kolb: Experiential education in the age of neuroscience. Journal of Experiential Education, 38(1), 73-95.

20. Seaman, J. (2008). Experience, reflect, critique: The end of the "learning cycles" era. Journal of Experiential Education, 31, 3-18.

21. Tuckman, B.W. (1965). Developmental sequences in small groups. Psychological Bulletin, 63, 384-399.

22. Yballe, L., \& O'Connor, D. (2000). Appreciative Pedagogy: Constructing Positive Models for Learning. Journal of Management Education. 